\title{
FORECASTING CORN PRODUCTION INDICATORS IN THE REPUBLIC OF SRPSKA
}

\author{
Miroslav Nedeljković ${ }^{1}$, Beba Mutavdžić ${ }^{2}$, Tihomir Zoranović ${ }^{3}$, Radmila Suzić ${ }^{4}$ \\ *Corresponding author E-mail: miroslavnedeljkovic2015@gmail.com
}

\begin{abstract}
A R T I C L E I N F O
A B S T R A C T

Original Article

Received: 20 May 2019

Accepted: 28 June 2019

The aim of this paper is to formulate quantitative models to predict future trends in corn production in the Republic of Srpska. The applied research methods are the descriptive analysis method, and the analytical statistical method, i.e. the Box-Jenkins Model based on the ARIMA model doi:10.5937/ekoPolj1903681N

UDC 631.16:633.15(497.6)

Keywords:

corn, production, The Republic of Srpska, forecast (Autoregressive Integrated Moving Average). The results of the research show that the corn production indicators, as the most important crop in the Republic of Srpska, will, despite the oscillations, show an increase in the last year of the five-year prediction period (2018-2022) compared to the previously analysed twenty-two year period (1996JEL: Q10, C53 2017). The formulation of such forecasting models is a good basis for planning the overall crop production in the Republic of Srpska.
\end{abstract}

(C) 2019 EA. All rights reserved.

\section{Introduction}

The Republic of Srpska, as one of the two entities in Bosnia and Herzegovina, belongs to a rural area characterized by a traditional agriculture with small and mixed types of household, and in whose overall structure of primary agricultural production, crop production is of the highest importance. Crop production is distinguished by the diversity of products used for human and animal food, or as raw materials for industrial processing. In addition, it covers most of the annual plants, so that its structure can

1 Miroslav Nedeljković, M.A., Ph.D. Student, University of Novi Sad, Faculty of Agriculture, D. Obradovica square no. 8, 21000 Novi Sad, Serbia, Phone: + 38766893 935, E-mail: miroslavnedeljkovic2015@gmail.com, ORCID ID (https://orcid.org/0000-0002-7393-2146)

2 Beba Mutavdžić, Ph.D., Associate Professor, University of Novi Sad, Faculty of Agriculture, D. Obradovica square no. 8, 21000 Novi Sad, Serbia, Phone: +381 62200 133, E-mail: bebam@polj.uns.ac.rs, ORCID ID (https://orcid.org/0000-0002-7631-0465)

3 Tihomir Zoranović, Ph.D., Associate Professor, University of Novi Sad, Faculty of Agriculture, D. Obradovica square no. 8, 21000 Novi Sad, Serbia, Phone: +381 62200 139, E-mail: tzoranovic@gmail.com, ORCID ID (https://orcid.org/0000-0003-2564-5000)

4 Radmila Suzić, Ph.D, Assistant Professor, Singidunum University, Danijelova no. 32, 11000 Beograd, Serbia, Phone: +381 64058 7419, E-mail: radmila.suzic@gmail.com, ORCID ID (https://orcid.org/0000-0003-1146-0304)

http://ea.bg.ac.rs 
easily and quickly be changed and adjusted to the conditions of a particular area-region, than in the case of permaculture and viticulture (Maletić, 2010).

In the structure of crop production in the Republic of Srpska, crops occupy a central place with a share of as much as $67.0 \%$ in total sown arable areas (The Institute of Statistics of the Republic of Srpska). Crops are of great commercial significance due to the fact that they are easily stored and transported, and are often subject to state interventionism, purchase and sale from state reserves or regulation of exports and imports.

According to the Institute of Statistics of the Republic of Srpska, corn is the most widespread crop on the arable land, and its share in the structure of areas under crops is more than two thirds $(65.6 \%)$. According to the same source, the production of corn in 2017 was 497,501.0 tons, which is 302,186.0 tons more than wheat, as the next most abundant crop in the Republic of Srpska. It should be pointed out that the economic significance of corn is reflected in the possibility of exploiting almost all of the overground biomass of plants. With various technological processes it is possible to produce more than 1500 various industrial products from the corn plant (Glamočlija, 2012). Corn is increasingly used for the production of bioethanol and biodegradable plastics (Torney et al., 2007; Schgiwietzke et al., 2008), while in underdeveloped and developing countries, corn is primarily used for human consumption, with the predicted rate of increase from 1.3\% by 2020 (Ortiz et al., 2010). Based on global forecasts, corn will become crop with the largest production by 2025, and the need for this culture will be doubled in developing countries by 2025 (Rosegrant et al., 2008).

Due to economic significance of corn in the Republic of Srpska, it is necessary to pay more attention to the future trends of its production. According to Mutavdžić (2009) in the market conditions of the economy, successful production depends on monitoring, analysis and forecasting of both the results and the most important factors affecting it. For this reason, the aim of the paper is to formulate quantitative models to anticipate future trends in corn production in the Republic of Srpska.

In previous surveys, many models of forecasting have been formulated in agriculture. Bearing in mind that the prediction was based on time series data, the applied models were from the class of ARIMA model that are widespread in the field of prediction. There are a large number of publications that have examined their implementation and validity.

When it comes to forecasting corn production in Serbia using the ARIMA model, Ilić et el., (2016) have constructed a model by which it is possible to determine the trend of the production of this crop in the upcoming period based on the previous time series. Suleman and Sarpong (2012) carried out modelling and forecasting of the production and consumption of corn in Ghana using the ARIMA model, while Badmus and Ariyo (2011), based on the time series of data and the application of the ARIMA model, performed the prediction of arable land and corn production in Nigeria until 2020. In addition to these, several other authors have been engaged in prediction of corn production during past years (Busay et al., 2015; Wei et al., 2015; Santosha et al., 2017; Sharma et al., 2018; Li and Zhu, 2018). In addition to corn production, the use of ARIMA model 
for the purpose of forecasting future production trends was also used in other crop species (Amin et al., 2014; Ramesh, 2015; Hossain and Abdulla, 2015; Iqbal et al., 2016).

In their research, some authors dealt with the forecasting of production parameters and other agricultural productions, such as cattle production (Novković et al., 2006), then vegetable production (Novković et al., 2013; Mutavdžić et al., 2014; Ivanišević et al., 2015; Mutavdžić and Novković., 2016), and the forecasting of economic parameters of agricultural production, such as price and price parity (Adanacioglu and Yercan, 2012; Mutavdzic et al., 2016; Novković et al., 2016; Jadhav et al., 2017).

\section{Materials and methods}

The defined objective of the research in the paper imposed the need to apply the appropriate research methods, namely:

- Descriptive analysis method, and

- Analytical and statistical methods.

The method of descriptive statistics was used for the analysis of the observed corn production indicators in the period 1996-2017 and includes basic statistical indicators such as the average value of the phenomenon, the variation interval (minimum and maximum), the coefficient of variation and the rate of change.

For the purpose of predicting the observed production parameters, autoregressive integrated processes of moving environments (ARIMA models) based on the analysis of time series were applied. The analysis of the time series refers to the observed twentytwo-year period, while the forecast relates to the next five-year period (2018-2022).

The general strategy for ARIMA modelling was drafted by Box and Jenkins (1970). The stages from which this methodology is composed of are:

- Model identification,

- Estimation of model parameters, and

- Checking the model adequacy

Model identification is a key step in the Box-Jenkins methodology, where the order of differentiation is determined, as well as the choice of the appropriate model and the order of the process. A narrow selection of several ARIMA models is performed on the basis of the graphic representation, where there is a need to perform the appropriate transformation of the initial values if the series contains a trend, a season, a variable variance, and the like. For this purpose, logarithmic transformation or differentiation is most often used in order to achieve stationarity. In addition, in order to determine the order of differentiation, common and partial autocorrelation functions are used, and in addition, the unit root test can be applied, and most often it is Dickey-Fuller test. Thereafter, based on the calculated ordinary and partial autocorrelation function, lines $p$ and $q$ are identified, which provides a temporary model. 
At the stage of estimation of model parameters, the parameters are evaluated using simple least squares (AR models) or non-linear least squares method (MA and ARMA models).

Checking the model adequacy implies checking the model's conformity with existing data as well as checking the adequacy of selected AR and MA components of the model. At this stage, the basic assumption of the model, whose fulfilment is checked, is that the random independent size of the is a white noise process with a mean zero and a constant variance. For the assessment of adequacy, a series of residues is analysed, which should have a normal distribution. For this purpose, the Jarque-Bera test is used. In addition to the basic assumption in selecting the model, it is necessary that the autocorrelation coefficients of the residual series are equal to zero. In doing so, the significance of individual autocorrelation coefficients can be tested or there can be performed a test of the hypothesis that all autocorrelation coefficients of the residual are equal to zero, using Box-Pierce statistics (Mutavdžić, 2009).

The series of observed phenomena in this paper were taken or formed on the basis of the available statistical publications of the Institute of Statistics of the Republic of Srpska, and all data processing was carried out with appropriate statistical software.

\section{Results and discussions}

In the analysed period, corn recorded a slight tendency of growth when it comes to all three measurements of production indicators. The average harvested area in the analysed twenty-two-year period was slightly over 141 thousand hectares, and was characterized by stability in its movement, which can be concluded from the calculated variation coefficient. Corn harvested area varied in the range of about 121 thousand hectares to almost 159 thousand hectares (Table 1.).

The average production of corn was about 592 thousand tons, and in relation to the harvested area, it showed unstable trend for the analysed period. Corn yields ranged from 2.3 to 6.4 tonnes per hectare, with an average of about 4.2 tonnes per hectare and a very similar trend of growth and stability of movement as well as production (Table 1.).

Table 1. Basic corn production indicators in the Republic of Srpska (1996-2017)

\begin{tabular}{|l|r|r|r|r|r|}
\hline \multirow{2}{*}{ Production indicators } & \multirow{2}{*}{$\begin{array}{c}\text { Average } \\
\text { value }\end{array}$} & \multicolumn{2}{|c|}{ Variation interval } & \multirow{2}{*}{$\begin{array}{c}\text { Variation } \\
\text { coefficient (\%) }\end{array}$} & $\begin{array}{c}\text { Change } \\
\text { rate (\%) }\end{array}$ \\
\cline { 3 - 4 } & 141.021 & 120.901 & 159.328 & 6,19 & 0,61 \\
\hline Area (ha) & 591.832 & 359.453 & 880.997 & 24,32 & 0,75 \\
\hline Production (t) & 4,18 & 2,31 & 6,40 & 24,68 & 0,79 \\
\hline Yield (t/ha) & & & \multicolumn{1}{c|}{ Maximum } & & \\
\hline
\end{tabular}

Source: Author's calculation

The model for the analysis and forecasting of the corn harvested area shows that the corn area in the previous year had statistically significant influence on the area of the corn in the current year, as well as the random process from the previous year (Table 2.). 
Table 2. Model for forecasting corn harvested area

\begin{tabular}{|l|r|r|r|r|r|r|}
\hline \multirow{3}{*}{ Paramet. } & \multicolumn{4}{|l|}{$\begin{array}{l}\text { Input: Corn haravested area } \\
\text { Transformations: D (1) } \\
\text { Model: (1,1,1) MS Residual=8357E4 }\end{array}$} \\
\cline { 2 - 7 } & Param. & $\begin{array}{c}\text { Asympt. } \\
\text { Std.Err. }\end{array}$ & $\begin{array}{c}\text { Asympt. } \\
\mathrm{t}(18)\end{array}$ & $\mathrm{p}$ & $\begin{array}{c}\text { Lower } \\
95 \% \text { Conf }\end{array}$ & $\begin{array}{c}\text { Upper } \\
95 \% \text { Conf }\end{array}$ \\
\hline Constant & 972,8894 & 2223,800 & 0,43749 & 0,666960 & $-3699,14$ & 5644,920 \\
\hline $\mathrm{p}(1)$ & $-0,8074$ & 0,232 & $-3,47368$ & 0,002711 & $-1,30$ & $-0,319$ \\
\hline $\mathrm{q}(1)$ & $-0,9424$ & 0,129 & $-7,29943$ & 0,000001 & $-1,21$ & $-0,671$ \\
\hline
\end{tabular}

Source: Author's calculation

The value of the corn harvested area based on the model shows an increase over the entire prediction period. At the end of the forecast period, it will be about $2.7 \%$ higher than the average corn harvested area achieved in the analysed period (Table 3.).

Table 3. Forecasting the corn harvested area (2018-22)

\begin{tabular}{|l|r|r|r|r|}
\hline \multirow{3}{*}{ Years } & \multicolumn{4}{|l|}{$\begin{array}{l}\text { Forecast; Model: (1,1,1) } \\
\text { Input: Corn harvested area } \\
\text { Start of origin: 1 End of origin: 22 }\end{array}$} \\
\cline { 2 - 5 } & Forecast & Lower 95,0000\% & Upper 95,0000\% & Std. Err. \\
\hline 2018 & 141811,6 & 122606,2 & 161017,1 & 9141,44 \\
\hline 2019 & 140252,7 & 111200,6 & 169304,8 & 13828,25 \\
\hline 2020 & 143269,8 & 108165,6 & 178374,0 & 16708,94 \\
\hline 2021 & 142592,1 & 101481,8 & 183702,5 & 19567,77 \\
\hline 2022 & 144897,7 & 99167,2 & 190628,2 & 21766,87 \\
\hline
\end{tabular}

Source: Author's calculation

The graphical representation of the trend of corn harvested area confirms the observed oscillations from the analysed period, as well as the fairly stable expected area values in the prediction period (Figure 1.)

Figure 1. The trend of corn harvested area

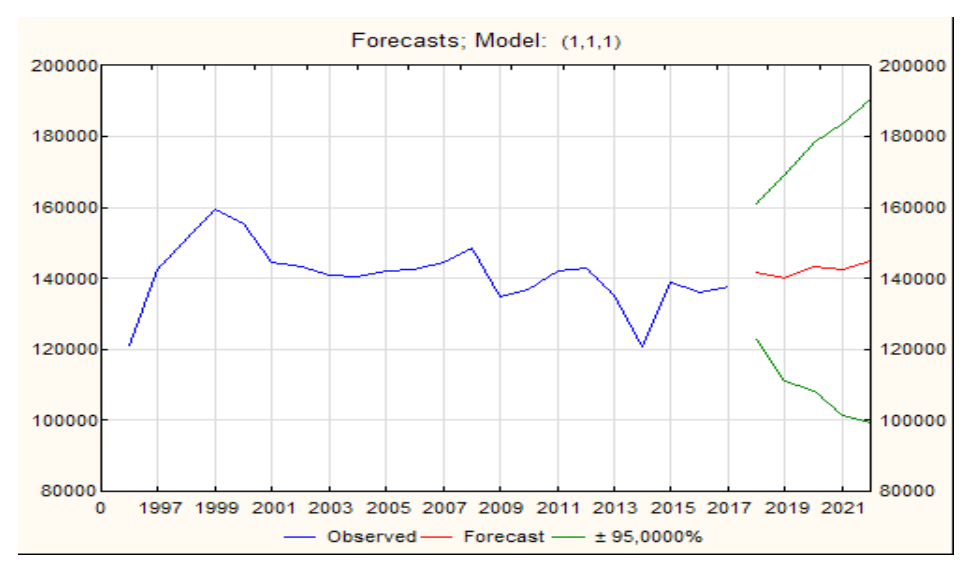

Source: Author's calculation 
The selected and estimated ARIMA $(2,1,0)$ model for the analysis and forecasting of corn production shows that the production of corn in the current year is under a statistically significant impact of the level of production from the previous year, but only if the analysis includes the production from the previous two periods (Table 4.).

Table 4. Model for forecasting corn production

\begin{tabular}{|l|r|r|r|r|r|r|}
\hline \multirow{3}{*}{ Paramet. } & \multicolumn{9}{|l|}{$\begin{array}{l}\text { Input: Corn production } \\
\text { Transformations: D (1) } \\
\end{array}$} \\
\cline { 2 - 7 } & Model: (2,1,0) MS Residual=3280E7 \\
\cline { 2 - 7 } & Param. & $\begin{array}{c}\text { Asympt. } \\
\text { Std.Err. }\end{array}$ & $\begin{array}{c}\text { Asympt. } \\
\mathrm{t}(18)\end{array}$ & $\mathrm{p}$ & $\begin{array}{c}\text { Lower } \\
95 \% \text { Conf }\end{array}$ & $\begin{array}{c}\text { Upper } \\
95 \% \text { Conf }\end{array}$ \\
\hline Constant & 9235,586 & 18335,64 & 0,50370 & 0,620584 & $-29286,2$ & 47757,33 \\
\hline $\mathrm{p}(1)$ & $-0,873$ & 0,23 & $-3,77034$ & 0,001401 & $-1,4$ & $-0,39$ \\
\hline $\mathrm{q}(1)$ & $-0,410$ & 0,24 & $-1,64490$ & 0,110645 & $-0,9$ & 0,10 \\
\hline
\end{tabular}

Source: Author's calculation

Predicted values of corn production in the following period show oscillations from year to year of the prediction period. The expected increase in corn production in the last year of the prediction period will be around 702,500 tons, which is about 111,000 tons more than the average production of corn in the analysed period (Table 5.).

Table 5. Forecasting the corn production (2018-22)

\begin{tabular}{|l|l|l|r|r|}
\hline \multirow{3}{*}{ Years } & \multicolumn{3}{|l|}{$\begin{array}{l}\text { Forecast; Model: (2,1,0) } \\
\text { Input: Corn production } \\
\text { Start of origin: 1 End of origin: 22 }\end{array}$} \\
\cline { 2 - 5 } & Forecast & $\begin{array}{c}\text { Lower } \\
95,0000 \%\end{array}$ & $\begin{array}{c}\text { Upper } \\
95,0000 \%\end{array}$ & Std. Err. \\
\hline 2018 & 722468,0 & 341957,9 & 1102978 & 181115,8 \\
\hline 2019 & 704260,9 & 320713,7 & 1087808 & 182561,4 \\
\hline 2020 & 649038,4 & 224299,3 & 1073777 & 202167,9 \\
\hline 2021 & 725820,4 & 255752,5 & 1195888 & 223743,6 \\
\hline 2022 & 702481,7 & 214817,4 & 1190146 & 232119,1 \\
\hline
\end{tabular}

Source: Author's calculation

The indicated characteristics of corn production are confirmed by the graphic representation of the production trend in the analysed period, as well as in the forecasting period (Figure 2.). 
Figure 2. Trend of corn production

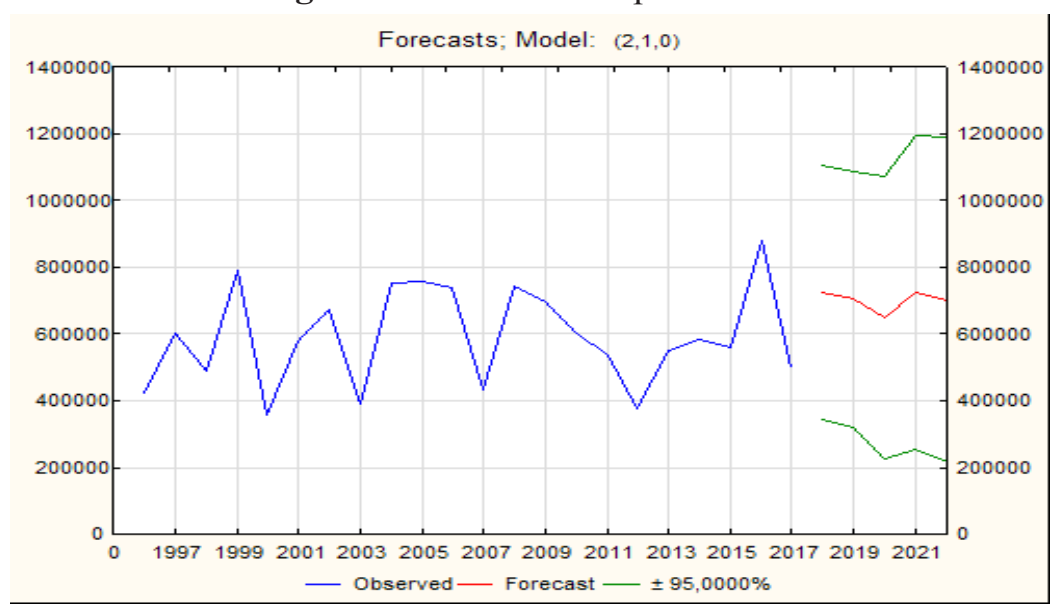

Source: Author's calculation

Model for forecasting corn yield shows that the yield of the previous year has a statistically significant impact on the current year's yield (Table 6.).

Table 6. Model for forecasting corn yield

\begin{tabular}{|l|l|c|c|c|c|c|}
\hline \multirow{3}{*}{ Paramet. } & \multicolumn{4}{|l|}{$\begin{array}{l}\text { Input: Corn production } \\
\text { Transformations: D (1) } \\
\text { Model: (2,1,0) MS Residual=3280E7 }\end{array}$} \\
\cline { 2 - 8 } & Param. & $\begin{array}{c}\text { Asympt. } \\
\text { Std.Err. }\end{array}$ & $\begin{array}{c}\text { Asympt. } \\
\mathrm{t}(19)\end{array}$ & $\mathrm{p}$ & $\begin{array}{c}\text { Lower } \\
95 \% \text { Conf }\end{array}$ & $\begin{array}{c}\text { Upper } \\
95 \% \text { Conf }\end{array}$ \\
\hline Constant & 0,067350 & 0,185569 & 0,36294 & 0,720659 & $-0,32105$ & 0,455750 \\
\hline $\mathrm{p}(1)$ & $-0,650440$ & 0,205611 & $-3,16346$ & 0,005116 & $-1,08079$ & $-0,220092$ \\
\hline
\end{tabular}

Source: Author's calculation

Predicted yield values based on the selected ARIMA model (1.1.0) show yield fluctuations from year to year of the prediction period. Regardless of the observed oscillations at the end of the forecast period, the yield of corn will be around $5.2 \mathrm{t} / \mathrm{ha}$, which is one ton more than the average corn yield from the analysed period (Table 7).

Table 7. Forecasting corn yield (2018-20)

\begin{tabular}{|l|c|c|c|r|}
\hline \multirow{3}{*}{ Years } & \multicolumn{3}{l|}{$\begin{array}{l}\text { Forecast; Model: (1,1,0) } \\
\text { Input: Corn yield } \\
\text { Start of origin: 1 End of origin: 22 }\end{array}$} \\
\cline { 2 - 5 } & Forecast & $\begin{array}{c}\text { Lower } \\
95,0000 \%\end{array}$ & $\begin{array}{c}\text { Upper } \\
95,0000 \%\end{array}$ & Std. Err. \\
\hline 2018 & 5,532389 & 2,720472 & 8,344307 & 1,343471 \\
\hline 2019 & 4,386642 & 1,407878 & 7,365406 & 1,423187 \\
\hline 2020 & 5,243039 & 1,556152 & 8,929925 & 1,761512 \\
\hline 2021 & 4,797160 & 0,853845 & 8,740475 & 1,884027 \\
\hline 2022 & 5,198334 & 0,820243 & 9,576425 & 2,091754 \\
\hline
\end{tabular}

Source: Author's calculation 
The corn yield is characterized by oscillations in both the analysed and the forecasting period which can be seen in a graphical presentation of the corn yield trend. The graphic representation also shows the tendency to increase yields in the prediction period (Figure 3.). It is opposite if we compare with Romania where authors Vasilescu et al. (2010) proved that corn and sunflower is less efficient than if we use extensive methods of production.

Figure 3. Corn yield trend

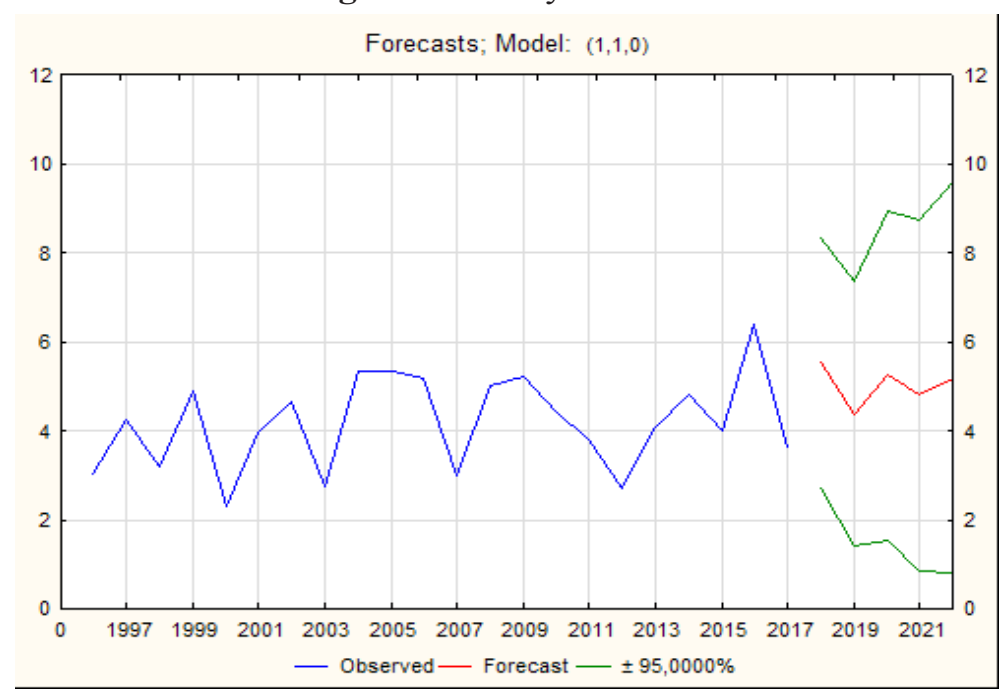

Source: Author's calculation

\section{Conclusions}

Based on the research of the time series of data and the formulation of adequate models for forecasting in this paper, the following can be concluded: reached levels of production indicators from the previous year, as well as the random processes, have the statistically significant influence on the trend of corn production indicators in the next five year period (2018-2022), taking into consideration the fact that corn is the most important crop in the Republic of Srpska. With the indicated oscillations in the next five-year period, it is expected that the corn harvested area in the last year of the prediction period will be 144,898 ha, which is $2.7 \%$ more than the average value in the previously analysed period. Also, during the entire period of forecasting and production of corn oscillations are present, while the production is expected to be at the level of about 702,482 tons in 2022, which is $16 \%$ more than the average value recorded in the period 1996-2017. Like the previous two indicators, the expected corn yield shows an increase in the last year of the forecast period and will amount to $5.2 \mathrm{t} / \mathrm{ha}$.

\section{Conflict of interests}

The authors declare no conflict of interest. 


\section{References}

1. Adanacioglu, H., \& Yercan, M. (2012). An analysis of tomato prices at wholesale level in Turkey: an application of SARIMA model, Custos e @gronegocio on line 8(4), 52-75.

2. Amin. M., Amanullah, M., \& Akbar, A. (2014). Time Series Modeling for Forecasting Wheat Production of Pakistan. The Journal of Animal \& Plant Sciences, 24(5), 1444-1451.

3. Badmus, M.A., \& Ariyo, O.S. (2011). Forecasting Cultivated Areas and Production of Maize in Nigerian using ARIMA Model. Asian Journal of Agricultural Sciences, 3(3), 171-176.

4. Box, G., \& Jenkins, G. (1970). Time Series of Analysis, Forecasting and Control, San Francisco: Holden-Day.

5. Busay, A., Velde, M., Fumagalli, D., \& Seguini, L. (2015). Improving operational maize yield forecasting in Hungary, Agricultural Systems, 141, 94-106.

6. Glamočlija, Đ. (2012). Posebno ratarstvo, žita i zrnene mahunarke, Univerzitet u Beogradu, Poljoprivredni fakultet, Zemun, Srbija, 19-37 [In English: Glamočlija, Đ. (2012). Specialty fields crop production, grains and legumes, University of Belgrade, The Faculty of Agriculture, Zemun, Serbia, 19-37].

7. Ilić, I., Jovanović, S., \& Milić, J.V. (2016). Forecasting corn production in Serbia using ARIMA model. Economics of Agriculture, 63(4), 1141-1156.

8. Iqbal, M. Ch., Jamshaid, T. M., \& Rashid, A.Q.A. (2016). Forecasting of Wheat Production: A Comparative Study of Pakistan and India. International Journal of Advanced Research (IJAR), 4(12), 698-709. doi: 10.21474/IJAR01/2449

9. Ivanišević, D. (2015). Forecast of Production-Economic Parameters for Vegetable Farming in Serbia, doctoral thesis, University of Novi Sad, The Faculty of Agriculture, Serbia.

10. Jadhav, V., Chinnappa, R. B.V., \& Gaddi, G.M. (2017). Application of ARIMA Model for Forecasting Agricultural Prices, Journal of Agricultural Science and Technology, 19, 981-992.

11. Li, B. \& Zhu, X. (2018). Forecast of Maize Production in Henan Province, American Journal of Plant Sciences, 9, 2276-2286.

12. Maletić, R., \& Popović, B. (2010). Production of Basic Agricultural Crops AP Vojvodina-Trends and Municipalities Ranking. Economics of Agriculture, 57(2), 275-292.

13. Mutavdžić, B. (2009). Analyzes and prediction of economics parameters in agriculture of Vojvodina, doctoral thesis, University of Belgrade, The Faculty of Agriculture, Zemun, Serbia. [ in Serbian: Mutavdžić, B. (2009), Analiza i predviđanje ekonomskih parametara i poljoprivredi Vojvodine, doktorska diserticija, Univerzitet u Beogradu, Poljoprivredni fakultet, Zemun, Srbija].

14. Mutavdžić Beba, Drinić Ljiljana, Novković, N., Ostojić, A., \& Rokvić Gordana (2014). Forecasting of vegetable production in Republic of Srpska, Central European Journal of Regional Development and Tourism „DETUROPE“, 6(1), 50-64.

15. Mutavdžić, B., \& Novković, N. (2016). Analysis and prediction of production parameters of cabbage in Serbia. XXI Counseling on biotechnology-Thematic Proceedings I, Faculty of Agronomy, Čačak, 167-172. [in Serbian: Analiza i predviđanje proizvodnih parametara kupusa u Srbiji, XXI Savetovanje o biotehnologiji sa međunarodnim učešćem-Tematski zbornik I, Agronomski fakultet, Čačak, 167-172.]. 
16. Mutavdžić, B., Novković, N., Vukelić, N., \& Radojević, V. (2016). Analysis and Prediction of Prices and Price Partyes of Corn and Wheat in Serbia. Journal on Processing and Energy in Agriculture, 20(2), 106-108.

17. Novković, N., Mutavdžić, B., \& Radojević, V. (2006). Changes in Animal Production in Vojvodina, at the begining of XXI Centuries. Contemporary Agriculture, 55(1-2), 14-20.

18. Novković, N., Mutavdžić, B., Ilin, Ž., \& Ivanišević, D. (2013). Potato Production Forecasting. Agro-knowledge Journal, 14(3), 345-355.

19. Novković, N., Mutavdžić Beba, Ivanišević, D., \& Matković, M. (2016). Analysis and prediction of cabbage price in Serbia, Book of Abstract, $5^{\text {th }}$ International Symposium on agricultural sciences, February 29-March, Banja Luka, Bosnia and Herzegovina, p.90.

20. Ortiz, R. S., Taba, S., Chavez T., Mezzalama, V. H., Xu, Y., Yan, J., \& Crouch, J. H. (2010). Conserving and enhancing maize genetic resources as global public goodsA perspective from CIMMYT. Crop Science, 50: 13-28.

21. Ramesh, D., Soumen, P., \& Srinivasa, V.R. (2015). Time Series Modeling for Trend Anaysis and Forecasting Wheat Production in India. International Journal of Agriculture, Environment \& Biotechnolog, 8, 303.

22. Rosengrant, M. C., Ringler, S. Msangi, T. Sulser, T. Zhu, S. Cline (2008). International Model for Policy Analisys of Agricultural Commodities and Trade (IMPACT): Model Description, International Food Research Institute: Washington, D.C.

23. Hossain, Md.M. \& Abdulla, F. (2015). Forecasting the Sugarcane Production in Bangladesh by ARIMA Model, Journal of Statistics Applications \& Probability, No.2, 297-303.

24. Sharma, P.K., Dwivedi, S., Ali, L., \& Arora, R.K. (2018). Forecasting Maize Production in India using ARIMA Model, Agro Economist-An International Journal, 5(1), 1-6.

25. Santosha, R., Singh, K.N., Prawin, A., Mrinmoy, R., Anirban, M., Kanchan, S., Prakash, K., \& Shekhavat, S.R. (2017). Forecasting maize yield using ARIMAGenetic Algorithm approach, Outlook on Agriculture, 46(4), 265-271.

26. Schgiwietzke, S., Kim, Y., Ximenez, E., Mosier, N., \& Ladish, M. (2008). Ethanol production from maize. Molecular Genetic Approaches to Maize Improvement, part VI, 347-364.

27. Suleman, I., \& Sarpong, S. (2012). Production and Consumption of Corn in Ghana: Forcasting Using ARIMA Models. Asian Journal of Agricultural Sciences, 4(4), 249-253.

28. The Institute of Statistics of the Republic of Srpska, Retrieved from http://www.rzs. rs.ba, (February 17, 2019)

29. Torney, F., Moeller, L., Scarpa, A., \& Wang, K. (2007). Genetic engineering approaches to improve bioethanol production from maize. Current Opinion in Biotechnology, 18, 193-199.

30. Vasilescu, I., Cicea, C., Popescu, G., \& Andrei, J. (2010). A new methodology for improving the allocation of crops cost production in Romania. Journal of Food, Agriculture and Environment, 8(2), 839-842.

31. Wei, J., Ning, J \& Li, F.Z. (2015). Forecasting of Corn Production in Shanxi ProvinceBased on the Exponential Smoothing Model. Tianjin Agricultural Sciences, 21, 84-85+97. 